\title{
PERAN BUZZER MEDIA SOSIAL DALAM MEMPERKUAT EKOSISTEM PEMASARAN DIGITAL
}

\author{
Bambang Arianto \\ Universitas Nahdlatul Ulama Yogyakarta \\ ariantobambang@unu-jogja.ac.id
}

\begin{abstract}
This article explains the role of social media buzzers that discuss the Pasar Kakilangit Mangunan Bantul to residents through hashtags which have become trending on Twitter topics. With creative content such as; videos, memes and texts, social media buzzers receive unique approval from Kakilangit Market to citizens. Through the hashtag \#PasarKakilangit which can be included in the Twitter Indonesia trending topic, the buzzers together support the promotion of Pasar Kakilangit products to viral and widely known by citizens. The presence of social media buzzers has built a new culture and new knowledge of the importance of trending Twitter topics in increasing the promotion of digital products and services. This article proves that media buzzer has supported positively in strengthening the digital marketing ecosystem.
\end{abstract}

Keywords: buzzer, social media, digital marketing

PENDAHULUAN

Survei Asosiasi Penyelenggara Jasa Internet (APJII) menyebut bahwa penetrasi pengguna internet di Indonesia mencapai $64,8 \%$ di tahun 2018. Hasil survei asosiasi tersebut menunjukkan bahwa penetrasi pengguna internet di Indonesia tahun 2018 naik $10,12 \%$ dari tahun sebelumnya. Kenaikan ini mencapai 27 juta pengguna. Artinya, ada 171,17 juta jiwa pengguna internet dari total 246,16 juta jiwa penduduk Indonesia berdasarkan data BPS (Badan Pusat Statistik). Dengan demikian, hasil riset tersebut mencatat, kontribusi pengguna internet per wilayah paling banyak terdapat di pulau Jawa yakni mencapai $55 \%$, kemudian disusul oleh Sumatera $\quad(21 \%)$, Sulawesi-Maluku-Papua (10\%), Kalimantan (9\%), serta Bali dan Nusa Tenggara (5\%) (Katadata.co.id, 2018).

Identifikasi tersebut menegaskan bahwa Indonesia kedepan akan menjadi salah satu pasar potensial dari ekonomi digital. Karena hampir semua sendi kehidupan saat ini melibatkan internet, termasuk pemanfaatan media sosial jadi tidak salah bila penelitian The Guardian, menyatakan telah terjadi lonjakan pendapatan iklan media sosial. Jika merujuk pendapatan iklan Facebook pada kuartal pertama tahun 2017 melonjak 51\% menjadi US\$ 7,86 miliar atau lebih tinggi dari ekspektasi awal yang senilai US\$ 7,68 miliar. Hal itu sedikit berbeda dari Twitter Inc yang tengah mengalami penurunan pendapatan iklan sebesar $11 \%$ menjadi US\$ 474 juta dan mencatatkan kerugian US\$ 62 juta. Gambaran perihal kenaikan iklan Facebook dan Twitter kian menunjukan akan pentingnya media sosial dalam membangun ekosistem bisnis digital (Kontan.co.id, 2018).

Data pengguna media sosial di Indonesia menurut temuan We Are Social, bersama dengan Hootsuite dalam laporan "Digital Around The World 2019" menunjukan bahwa ada sekitar 150 juta pengguna media sosial dengan penetrasi 49 persen pada Januari 2019. Platform media sosial publik yang paling diminati di Indonesia yaitu Youtube (88 persen), Facebook (81\%), Instagram (80\%) dan Twitter (52\%). Sedangkan generasi yang 


\section{BAMBANG ARIANTO \\ Peran Buzzer Media Sosial Dalam Memperkuat Ekosistem Pemasaran Digital}

paling banyak menggunakan berasal dari generasi $\mathrm{Z}$ dan milenia. Generasi $\mathrm{Z}$ dalam konteks ini berumur sekitar $18-24$ tahun dan generasi milenial berkisar 25-34 persen (Fahmi, 2019).

Fenomena tingginya pengguna media sosial melahirkan para aktor komunikator yang memiliki pengaruh hingga bisa membangun citra positif seperti peran Buzzer dan Influencer. Kedua aktor penting inilah yang akan sangat menentukan kesuksesan sebuah pemasaran digital termasuk dalam upaya mempromosikan desa wisata, hingga pada berbagai produk serta jasa di tingkatan usaha mikro, kecil dan menengah (UMKM). Akan tetapi, teknik pemasaran digital tentu tidak bisa berjalan sistematis tanpa didukung oleh konten-konten yang kreatif, dengan begitu salah satu hal penting dalam pemasaran digital adalah mempersiapkan konten yang menarik, inovatif dan kreatif. Konten kreatif bisa membuat para pengguna media sosial (warganet) tertarik untuk selalu mengikuti informasi produk yang ditampilkan. Artinya konten kreatif merupakan bagian dari kampanye kreatif yang bisa membangun budaya partisipatif dalam masyarakat digital (Arianto, 2015).

Konten kreatif bisa membuat pengguna internet lainnya mulai mengenal informasi, produk dan jasa yang di tawarkan, sebut saja video yang terbukti menjadi bagian terpenting dari strategi kampanye konten. Apalagi video di media sosial menghasilkan interaksi lebih banyak share daripada kombinasi teks dan gambar. Hal itu dikarenakan sekitar 90\% warganet lebih cepat menangkap pesan dari konten video. Sedangkan hanya 10\% yang hanya menangkap pesan dari kombinasi teks, meme ataupun gambar.

Dengan demikian, dalam pemasaran digital sangat erat kaitannya dengan pemilihan konten yang unsur viralnya (unsur share) tinggi. Sehingga dengan begitu dapat mendorong para warganet tertarik dan ikut membagikan dengan cepat. Hal inilah yang dikenal sebagai viral marketing sebagai teknik pemasaran yang digunakan perusahaan untuk menyebarkan pesan menggunakan jejaring sosial dengan tujuan meningkatkan brand awareness. Viral marketing dilakukan agar pesan yang disampaikan dapat diteruskan oleh penerimanya, sehingga terjadi penyebaran yang berlipat (Paradistya, 2014), akan tetapi konten-konten tersebut tidak bisa menjadi viral atau pembicaraan warganet, apabila tidak ada peran "buzzer" maupun "influencer" yang bisa memperkuat konten tersebut di media sosial.

Dalam konteks bisnis digital, buzzer merupakan sosok akun-akun media sosial yang sangat aktif "memperkuat" dalam upaya mempromosikan dan mengkampanyekan suatu merek dagang bisnis. Sedangkan influencer merupakan sosok yang paling berpengaruh dalam media sosial dan tentunya memiliki follower melebihi buzzer media sosial, sehingga biasanya influencer selalu berperan membangun isu utama yang kemudian diperkuat oleh peran akun buzzer. Meski demikian, untuk memilih influencer dan buzzer yang tepat kita harus memperhatikan tingkat grafik para buzzer tersebut di media sosial. Termasuk, gaya penyampaian, hingga gaya penuh humor dalam menyapa followers-nya. Jadi tidak salah bila tren pemasaran digital saat ini lebih banyak mempergunakan tenaga buzzer dan influencer dari para selebriti, tokoh berpengaruh serta warganet yang memiliki ratusan ribu follower.

Berkembangnya media sosial telah mendorong lahirnya para aktor utama dalam konteks warganet seperti influencer, buzzer dan follower. Ketiga aktor penting inilah yang akan sangat menentukan kesuksesan model pemasaran digital terutama dalam upaya mempromosikan produk dan jasa di tingkatan UMKM. Sedangkan mengacu studi yang dilakukan Moriansyah (2015) bahwa media sosial merupakan alat komunikasi pemasaran yang dapat dikategorikan berdasarkan alasan atau motivasi pemasar menggunakan media sosial (antecedants) dan target dari progam pemasaran (consequences) yang dapat diraih dengan menggunakan media sosial., dengan 


\section{JURNAL OPTIMUM, Volume 10, Nomor 1 Maret 2020}

demikian teknik pemasaran digital dikatakan sangat efektif karena dekade terakhir warganet banyak memperhatikan saran dari influencer dan buzzer media sosial untuk mengambil keputusan membeli sebuah produk atau jasa yang dipromosikan baik melalui Instagram, Twitter, Facebook dan Youtube. Dengan begitu keberadaan media sosial telah menjadi media penyebaran informasi yang sangat efektif guna mempengaruhi persepsi banyak orang, bahkan, era revolusi industri 4.0 telah membuat semua sendi kehidupan dipengaruhi oleh media sosial.

Dalam konteks bisnis digital, istilah buzzer mengacu pada konsep buzz marketing, yaitu aktivitas atau kegiatan pemasaran suatu produk pada saluran media komunikasi untuk menciptakan gangguan. Gangguan tersebut ditujukan pada kompetitor untuk menarik target audience. Buzzer inilah yang akan melempar isu di media sosial, terutama twitter, sehingga menjadi perbincangan luas khalayak (viral). Agar sebuah tweet menjadi viral, akun Twitter yang menjadi buzzer didukung oleh puluhan bahkan ratusan akun robot (dikenal dengan akun bot, yang dibuat untuk pekerjaan otomatis seperti retweet). Atau sesama akun twitter yang menjadi buzzer tersebut saling sahut menyahut tentang suatu isu yang sedang diperbincangkan. Dengan begitu akun buzzer menjadi aktor penting dalam menyebarluaskan kebencian untuk kepentingan politik. Golongan buzzer politik ini secara sempit membela habis-habisan kepentingan politiknya, dan mencerca sepuas-puasnya yang menjadi lawan politik mereka (Syahputra, 2017)

Dalam leksikon politik digital istilah buzzer politik merupakan sebuah aktivitas pemasaran politik yang berisi informasi pada saluran komunikasi digital untuk menciptakan efek mempengaruhi dan menjadi perbincangan luas (viral) hingga kemudian menjadi opini publik (Arianto, 2017) tetapi kedua studi tersebut lebih mengulas buzzer politik dan belum membahas dalam konteks buzzer bisnis yang bergerak dalam bisnis digital. Jika ditelisik buzzer media sosial merupakan sosok akun media sosial baik anonim maupun nyata (real) yang menyebarluaskan, mengkampanyekan, mendengungkan suatu pesan atau konten dengan tujuan memperkuat suatu pesan dan konten tersebut. Dalam konteks ini pesan bisa merupakan berbagai produk dan jasa yang dikemas menjadi konten kreatif seperti video, gambar (image) atau teks (Arianto, 2019).

Meski demikian selama ini buzzer sebagai profesi yang dipandang negatif karena aktivitasnya identik menyebarkan kontenkonten yang menyerang atau merugikan orang lain, daripada menyajikan isu-isu aktual. Akan tetapi, tipologi tersebut tentu berbeda dengan buzzer bisnis. Sebab, buzzer bisnis lebih patuh pada regulasi dan etika bermedia sosial. Bahkan materi konten yang disampaikan buzzer bisnis tidak boleh membawa muatan fitnah, ujaran kebencian dan isu-isu suku, agama dan ras (SARA) ketika mempromosikan sebuah produk dan jasa kepada warganet.

Artikel ini akan melanjutkan penelitian Arianto (2019) yang mengelaborasi peran buzzer media sosial dalam branding produk UMKM Daerah Istimewa Yogyakarta. Tetapi perbedaan penelitian ini terletak pada peran buzzer dalam upaya memperkuat ekosistem pemasaran digital melalui media sosial Twitter dan Instagram. Pendek kata, dengan semakin berperannya para buzzer media sosial dalam bisnis digital mengajak pada pertanyaan; Bagaimana peran buzzer media sosial dalam memperkuat ekosistem pemasaran digital? Batasan dalam penelitian ini hanya seputar peran dan implikasi para buzzer media sosial dalam memperkuat ekosistem pemasaran digital.

REVIEW LITERATUR

Media Sosial

Media sosial telah menjadi salah satu saluran yang sangat mempengaruhi semua sektor kehidupan publik. Dalam konteks pengertian media sosial merupakan sebuah kelompok aplikasi berbasis internet yang 


\section{BAMBANG ARIANTO \\ Peran Buzzer Media Sosial Dalam Memperkuat Ekosistem Pemasaran Digital}

dibangun atas dasar ideologi dan teknologi web 2.0 dan memungkinkan penciptaan dan pertukaran user generated content. Dengan demikian, media sosial merupakan sebuah media berbasis kecanggihan teknologi yang diklasifikasikan dari berbagai bentuk seperti majalah, forum internet, weblog, blog sosial, microblogging, wiki, foto atau gambar, video peringkat dan bookmark sosial (Kaplan \& Haenlein, 2010).

Dalam perkembanganya media sosial yang dikenal dengan masyarakat jejaring memiliki empat bentuk kekuatan diantaranya; Pertama, kekuatan jaringan merupakan kekuatan aktor dan organisasi yang termasuk inti dari masyarakat jaringan global. Kedua, kekuatan jaringan yang dihasilkan dapat mengoordinasikan interaksi sosial dalam jaringan. Dalam hal ini, kekuasaan dilakukan bukan dengan pengecualian dari jaringan tetapi dengan penerapan aturan inklusi. Ketiga, kekuatan aktor sosial atas aktor lainnya dalam sebuah jaringan. Keempat, kekuatan untuk memprogram jaringan spesifik sesuai dengan minat dan nilai-nilai yang berbeda termasuk mengikuti aliansi strategis antara aktor dominan dari berbagai jaringan (Castells, 2007).

\section{Pemasaran Digital}

Penelitian ini lebih menekankan pada pemasaran digital (digital marketing) akan tetapi tetap mengacu pada konsep dasar pemasaran. Menurut Kotler (2012) pemasaran merupakan proses mengelola hubungan pelanggan yang menguntungkan. Tujuan ganda pemasaran adalah untuk menarik pelanggan baru dengan menjanjikan nilai superior dan mempertahankan serta menumbuhkan pelanggan saat ini memberikan kepuasan. Selain itu dalam konteks bisnis digital, Kotler (2001) pemasaran online adalah pemasaran yang dilakukan melalui sistem komputer online secara interaktif yang menghubungan antara konsemen dan penjual secara elektronik (Kotler, 2001)
Ada beberapa keuntungan dari internet marketing bila perusahaan yang menggunakannya diantaranya; Pertama, baik perusahaan kecil maupun perusahaan besar dapat melakukannya. Kedua, tidak terdapat batas nyata dalam ruang beriklan jika dibandingkan dengan media cetak dan media penyiaran. Ketiga, akses dan pencarian keterangan sangat cepat jika dibandingkan dengan surat kilat atau bahkan faksimile. Keempat, situsnya dapat dikunjungi oleh siapapun, dimanapun dan kapanpun. Kelima, belanja dapat dilakukan secara lebih cepat.

Istilah pemasaran digital adalah konsep yang relatif baru di bidang pemasaran. Pemasaran digital telah memungkinkan penerapan praktik pemasaran yang diperlukan untuk menciptakan dan menargetkan pelanggan dengan cara yang lebih tepat waktu dan modis. Teknologi digital memfasilitasi lingkungan pemasaran digital, sehingga memperluas ruang bagi pemasar untuk berinteraksi dengan pelanggan mereka. Dalam lanskap teknologi yang muncul, komunikasi antara pemasar dan pelanggan adalah dua arah, bergerak naik turun hubungan. Selain itu, pentingnya frekuensi posting tetap merupakan komponen yang mendasari strategi pemasaran media sosial organik (Lancaster, 2010).

\section{Buzzer Media Sosial}

Dalam langgam bisnis digital di Indonesia istilah buzzer media sosial sudah dikenal sejak kehadiran media sosial Twitter tahun 2006. Keberhasilan buzzer dalam mempromosikan sebuah brand produk, menyebabkan peran buzzer mulai banyak digunakan. Meski demikian penggunaan Twitter dalam dunia bisnis sedikit menurun semenjak kehadiran platform Instagram yang juga mengambil alih Facebook. Akan tetapi dalam upaya membangun citra positif produk dan jasa platform Twitter masih tetap memegang kendali. Dikarenakan informasi dalam Twitter lebih cepat beredar dan juga memiliki fasilitas trending topik yang tidak dimiliki media sosial lainnya. Dengan begitu 
definisi buzzer merupakan sosok akun media sosial baik anonim atau nyata (real) yang setiap saat menyebarluaskan, mengkampanyekan, mendengungkan suatu pesan atau konten dengan tujuan memperkuat suatu pesan atau konten tersebut menjadi opini publik. Pesan atau konten bisa berupa informasi, produk dan jasa kepada warganet. Dengan kata lain buzzer media sosial lebih identik dengan upaya memperkuat suatu pesan (Arianto, 2019).

\section{METODE PENELITIAN}

Metode Penelitian ini menggunakan pendekatan kualititatif eksplanatoris yang dimulai dari Juni 2018 hingga hingga Juli 2019. Objek penelitian merupakan pasar tradisional yang merupakan salah satu destinasi wisata terbaru di wilayah Yogyakarta. Adapun buzzer media sosial dalam penelitian ini merupakan relawan dari Generasi Pesona Indonesia (Genpi). Penelitian ini menggunakan teknik wawancara mendalam (in-depth interview) kepada buzzer media sosial yang terlibat dalam mempromosikan Pasar Kakilangit. Pemilihan ini ditujukan untuk memilih informasi penelitian dan pengumpulan data. Adapun untuk mengukur validitas penelitian, peneliti menggunakan triangulasi sumber dengan membandingkan data hasil pengamatan dan wawancara, keadaan dengan perspektif orang, dan hasil wawancara dengan isi dokumen (Moleong, 2005).

\section{HASIL DAN PEMBAHASAN}

Buzzer Bisnis

Sistem kerja buzzer media sosial dalam memperkuat suatu pesan atau konten, memiliki tiga kategori yakni, (1) membangun citra positif (supporting), (2) mengklarifikasi citra (defensif) (3) menyerang dan merusak citra pesaing (offensive). Akan tetapi dalam konteks bisnis digital buzzer bisnis lebih banyak bergerak di ranah supporting dan defensif. Sedangkan dalam konteks politik, buzzer lebih banyak bergerak dalam kategori offensive dengan memanfaatkan informasi baik itu fakta maupun hasil investigasi invidual. Dengan begitu buzzer media sosial dikenal memiliki kemampuan amplifikasi pesan yang dengan cepat bisa membangun percakapan dan bergerak dengan motif tertentu. Hal itu dikarenakan karakteristik kerja buzzer media sosial menyerupai "lonceng" atau "bel" yang seringkali membuat suara bising. Dengan demikian inilah yang membuat pesan yang disampaikan bisa cepat viral atau tersebar luas kepada warganet (Arianto, 2019).

\section{Tabel 1.}

\begin{tabular}{|c|c|c|}
\hline & Buzzer Bisnis & Buzzer Politik \\
\hline Definisi & $\begin{array}{l}\text { Akun media sosial } \\
\text { baik anonim atau } \\
\text { nyata (real) yang } \\
\text { setiap saat } \\
\text { menyebarluaskan, } \\
\text { mengkampanyekan } \\
\text { dan } \\
\text { mendengungkan } \\
\text { suatu pesan atau } \\
\text { konten bisnis } \\
\text { kepada warganet } \\
\text { dengan tujuan } \\
\text { memperkuat suatu } \\
\text { pesan atau konten } \\
\text { bisnis tersebut } \\
\text { menjadi opini } \\
\text { publik. }\end{array}$ & 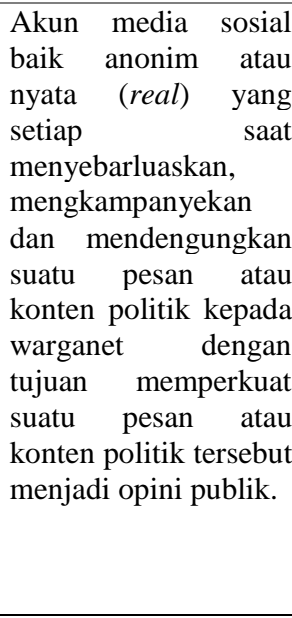 \\
\hline Follower & $>2000$ Follower & $>500$ Follower \\
\hline Sistem Kerja & $\begin{array}{l}\text { - Membangun citra } \\
\text { positif } \\
\text { (supporting) } \\
\text { - Mengklarifikasi } \\
\text { citra (defensif) }\end{array}$ & $\begin{array}{ll}\text { - } & \text { Membangun citra } \\
\text { positif } \\
\text { (supporting), } \\
\text { - } \\
\text { Mengklarifikasi } \\
\text { citra (defensif) } \\
\text { - } \\
\text { Menyerang dan } \\
\text { merusak citra } \\
\text { pesaing } \\
\text { (offensive). }\end{array}$ \\
\hline Konten & Meme, Video, Teks & Meme, Video, Teks \\
\hline Media Sosial & $\begin{array}{l}\text { Twitter, Facebook, } \\
\text { Instagram, } \\
\text { Whatsapp dan } \\
\text { Youtube }\end{array}$ & $\begin{array}{lr}\text { Twitter, } & \text { Facebook, } \\
\text { Instagram } & \text { dan } \\
\text { Whatsapp } & \end{array}$ \\
\hline
\end{tabular}




\begin{tabular}{|c|c|c|}
\hline Karakter & 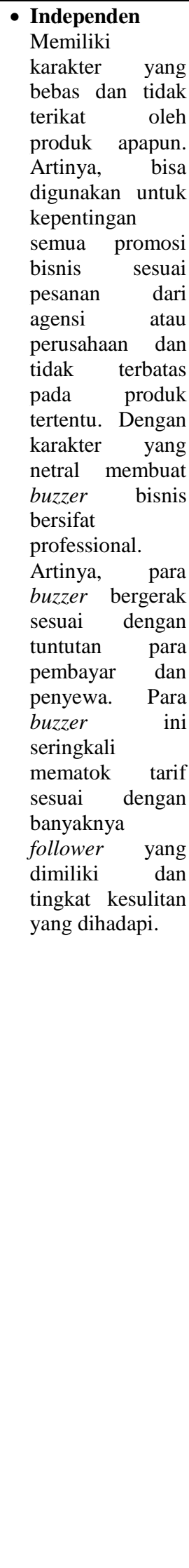 & 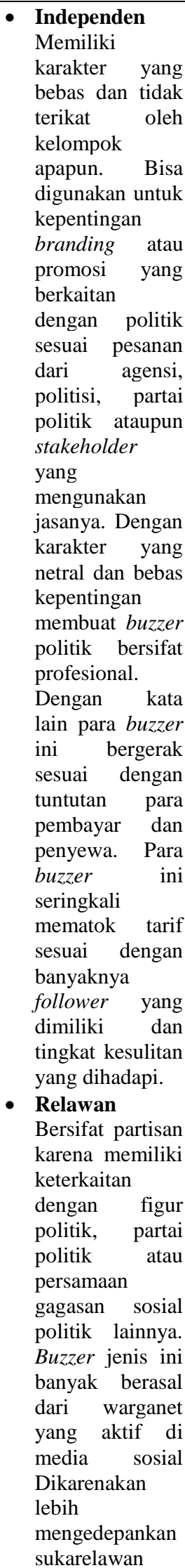 \\
\hline
\end{tabular}

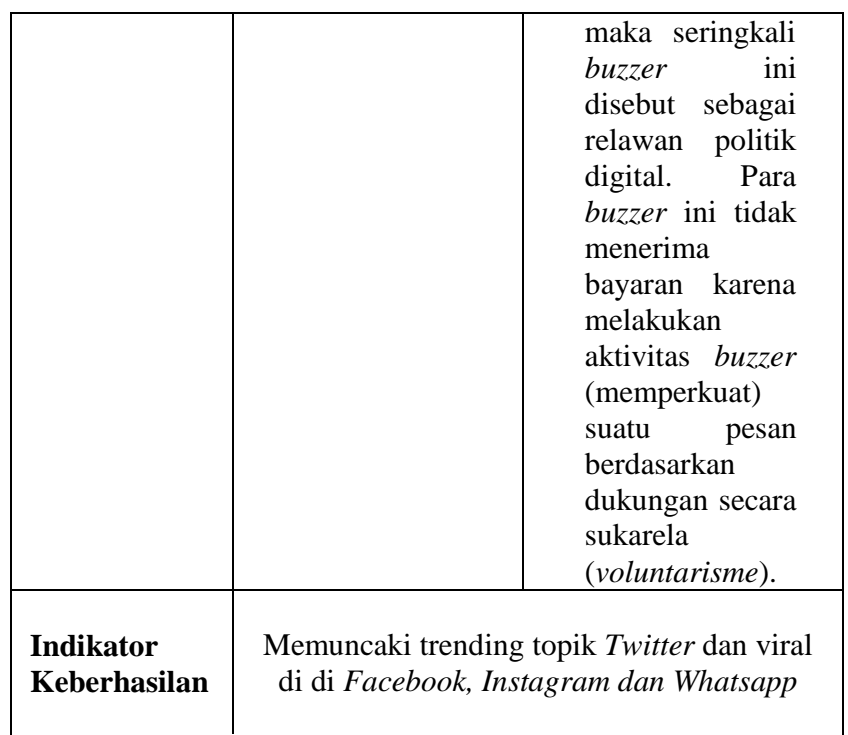

Sumber: Arianto (2019)

Kedua tipologi buzzer media sosial ini memiliki kreativitas dan inovasi yang sama dalam mengunggah postingan hingga memberikan efek mempengaruhi bagi warganet lainnya untuk bertindak sama dengan nalarnya. Dalam konteks bisnis digital, selain buzzer media sosial dikenal juga dikenal istilah influencer yang merupakan sosok akun media sosial yang memiliki follower diatas 10.000 dan mempunyai pengaruh kuat terhadap follower-nya sehingga dapat memberikan efek buzz bersama-sama di media sosial. Hal ini disebabkan karakter influencer biasanya merupakan sosok yang memiliki kreativitas dan inovasi yang berbeda dengan yang lain dalam mengunggah postingan. Baik buzzer dan influencer inilah yang seringkali mempengaruhi opini publik hingga melahirkan banyak dukungan yang dapat tergambar dari beragam trending topik Twitter.

Alhasil, bila kemudian sebuah tagar bisa memuncaki trending topik maka secara otomatis dapat diamplikasi oleh media mainstrem untuk dijadikan berita utama (headline). Hal inilah yang membuat peran trending topik Twitter bisa menjadi salah satu alternatif mem-branding produk dan isu apapun agar dikenal secara cepat oleh warganet. Sedangkan follower yang merupakan bagian warganet hanya berperan 


\section{JURNAL OPTIMUM, Volume 10, Nomor 1 Maret 2020}

sebagai sosok yang melakukan share atau retweet postingan konten dari akun buzzer dan influencer. Dengan demikian, perkembangan beriklan dan branding melalui akun buzzer media sosial terbilang efektif karena media sosial merupakan media yang cepat menjangkau semua kalangan.

Apalagi hingga saat ini semua orang baik dari perkotaan hingga perdesaan semakin terpacu untuk memiliki media sosial hingga di perdesaan. Dikarenakan memiliki akun media sosial dengan follower yang besar bisa menjadi salah satu lahan bisnis baru di era digital saat ini. Sebab, biasanya para vendor akan mencari buzzer yang memiliki follower besar. Meski demikian terlebih dahulu akan dilihat karakteristik followers dari akun buzzer tersebut. Apakah cocok dengan karakter produk dan jasa yang ingin diviralkan. Kalau dirasa cocok, maka vendor akan segera menyewa buzzer tersebut dengan perjanjian kerjasama yang telah disepakati antara kedua belah pihak. Hingga saat ini, bukan hanya produk dan jasa saja yang bisa menggunakan jasa buzzer, tetapi juga kegiatan sosial bisa dipromosikan melalui buzzer media sosial. Tujuannya agar produk dan jasa tersebut dapat dikenal luas oleh warganet atau dengan kata lain untuk tujuan membangun citra positif.

\section{Sekilas Pasar Kakilangit}

Pasar Kakilangit menjadi salah satu destinasi wisata baru di wilayah Daerah Istimewa Yogyakarta. Pasar pekanan ini berlokasi di Desa Wisata Mangunan, Dlingo, Bantul Yogyakarta. Lokasi pasar ini ada ditengah kawasan wisata Dlingo Imogiri Bantul, sehingga cukup dekat dengan Hutan Pinus Asri, Watu Goyang dan Lintang Sewu. Pasar Kakilangit hadir pertama kali pada 10 Desember 2017 dan mulai dibuka pada hari Sabtu dan Minggu mulai pukul 06.00 - 11.00. Pasar pekanan yang tergolong unik ini mencoba menawarkan perpaduan antara wisata dan kuliner. Hal itu dapat dilihat dari berbagai sajian tradisional yang ditawarkan oleh para warga setempat yang sekaligus menjadi pelaku usaha kuliner. Dari sini kemudian tercetus ide untuk membuka pasar mini yang menyajikan anek macam makanan "ndeso' tradisional.

Pasar ini diinisiasi oleh relawan Generasi Pesona Indonesia (Genpi) Jogja agar menjadi salah satu destinasi digital yang dicanangkan oleh Kementerian Pariwisata. Dimana pada Rakornas Pariwisata di Nusa Dua (22-23 Maret 2018) salah satu tema adalah destinasi digital. Genpi merupakan komunitas relawan digital yang beranggotakan kaum muda dengan tujuan mempromosikan beragam destinasi wisata Indonesia. Genpi dibentuk oleh para warganet yang aktif di media sosial dengan beragam keahlian seperti; blogger, videografer dan fotografer. Para relawan ini memanfaatkan media sosial Twitter dan Instagram. Salah satu tujuan menggunakan Twitter yakni agar setiap pekan bisa menaikan tagar \#PasarKakilangit hingga menjadi trending topik Indonesia.

Dilihat perkembangannya hingga saat ini, Pasar Kakilangit telah menghadirkan 15 pedagang kuliner tradisional khas Dlingo, yang dibuka hanya setiap sabtu dan minggu. Di Pasar Kakilangit terdapat beragam kuliner khas Yogyakarta diantaranya; Tiwul, Pecel, Gudeg Manggar, Dawet Ayu, Wedang Uwuh, Kelanan, Brongkos, Sego Ireng, Sego Horeng dan masih banyak lagi kuliner yang ditawarkan. Jika selama ini wisatawan yang datang hanya menikmati lokasi foto berlatar belakang keindahan alam, maka dengan hadirnya Pasar Kalilangit, wisawatan juga dapat menikmati kuliner khas masyarakat Mangunan, Dlingo, Bantul. Selain itu menurut para buzzer dari Genpi, Pasar Kakilangit juga bakal menggelar aneka kerajinan produk masyarakat Mangunan dan sekitarnya.

Kehadiran Pasar Kakilangir diharapkan dapat memperpanjang waktu kunjung wisatawan, menghadirkan variasi atau alternatif pendukung destinasi serta memecah konsentrasi kunjungan wisatawan. Selain itu, Pasar Kakilangit ditujukan sebagai sarana penunjang pengembangan potensi daerah serta meningkatkan pertumbuhan ekonomi mikro 


\section{BAMBANG ARIANTO \\ Peran Buzzer Media Sosial Dalam Memperkuat Ekosistem Pemasaran Digital}

masyarakat setempat. Oleh sebab itu, seluruh kegiatan Pasar Kakilangit dikelola oleh masyarakat setempat, mulai dari pedagang hingga pengisi acara. Dalam bertransaski di Pasar Kakilangit, pembayarannya bukan menggunakan uang, akan tetapi berupa koin kayu yang bernilai 1 (Rp. 1000), 2 (Rp.2000), dan 5 (Rp.5000). Satu kantong uang koin dari kayu nilanya sebanyak Rp. 30 ribu.

Sedangan untuk bisa bertransaksi di Pasar Kakilangit yakni setiap pengunjung bisa menukarkan uang rupiah dengan koin kayu yang tersedia di gubuk lurah pasar. Jika berbelanja tidak sampai menghabiskan koin, maka sisa koin dapat ditukarkan uang kembali. Meski baru dibuka ini, Pasar Kakilangit banyak menarik perhatian pengunjung. Hal itu terlihat dari peningkatan jumlah pengunjung yang datang pada pagi hari untuk menikmati suasana dan kuliner yang disajikan di Pasar Kakilangit. Meski Pasar Kakilangit hanya terfokus pada makanan tradisional atau makanan "ndeso". Tetapi, Pasar Kakilangit juga menyediakan beragam sajian kesenian tradisional yang bisa ditemui didepan setiap stand kuliner.

\section{Konten Kreatif dan Inovatif}

Dalam teknik pemasaran digital, hal yang terpenting adalah menghasilkan berbagai bentuk konten kreatif dan inovatif. Dikarenakan konten merupakan indikator utama dalam menarik perhatian warganet untuk melihat produk dan jasa yang ditawarkan. Bila kontennya monoton dan tidak menarik, tentu akan sulit menarik perhatian warganet. Dalam penelitian ini, ada beberapa bentuk pesan konten pemasaran digital yang dirancang diantaranya; (1) Tulisan berita positif, (2) Meme (3) Video, (4) Teks. Kesemua jenis konten pemasaran digital tersebut disatukan dalam bentuk brief atau narasi tunggal yang kemudian disebar kepada semua buzzer media sosial. Narasi tunggal yang dimaksud adalah alur narasi yang berisi konten teks serta menjadi panduan bersama bagi para buzzer media sosial dalam mempromosikan sebuah produk. Dengan kata lain, teks media sosial yang akan di posting (caption) diharapkan tidak terlalu melebar dari brief yang sudah ditentukan dari pusat.

Dalam penelitian ini dikenal, beberapa bentuk konten yang diproduksi oleh para buzzer media sosial diantaranya;

\section{Berita Positif}

Dalam proses pemasaran digital ini para buzzer seringkali mengandalkan tulisan di berbagai media digital yang mengulas perihal Pasar Kakilangit. Tulisan ini ditujukan agar publik dapat dengan cepat mencari berita positif terkait sejarah dan serba-serbi yang ada di Pasar Kakilangit. Oleh sebab itu, para buzzer bisnis juga melatih kaum muda di sekitar Pasar Kakilangit untuk dapat menulis hingga bisa memiliki banyak berita positif seputar Pasar Kakilangit. Tim yang membuat konten ini tergabung dalam Content Creator. Dalam tim ini yang dapat bergabung ada beberapa pegiat penulis muda (blogger) dan ilustrator. Biasanya, sebelum membuat materi tulisan positif, tim ini diberikan brief tertentu agar sesuai arahan koordinator atau bisa juga memberikan usulan sesuai dengan kreativitas masing-masing. Dengan cacatan setiap tulisan dan berita positif yang dibuat agar dapat di lacak kata kunci (keyword) oleh mesin pencari seperti google. Oleh sebab itu konten kreator diwajibkan dapat mencantumkan hiperlink dari tulisannya. Biasanya tulisan-tulisan ini kemudian disebar ke berbagai Blog pribadi, Kompasiana, Kaskus, dan beberapa situs komunitas lainnya. Selain itu, dari materi berita positif ini bisa dijadikan rujukan bersama dalam membuat ilustrasi dan meme politik. 


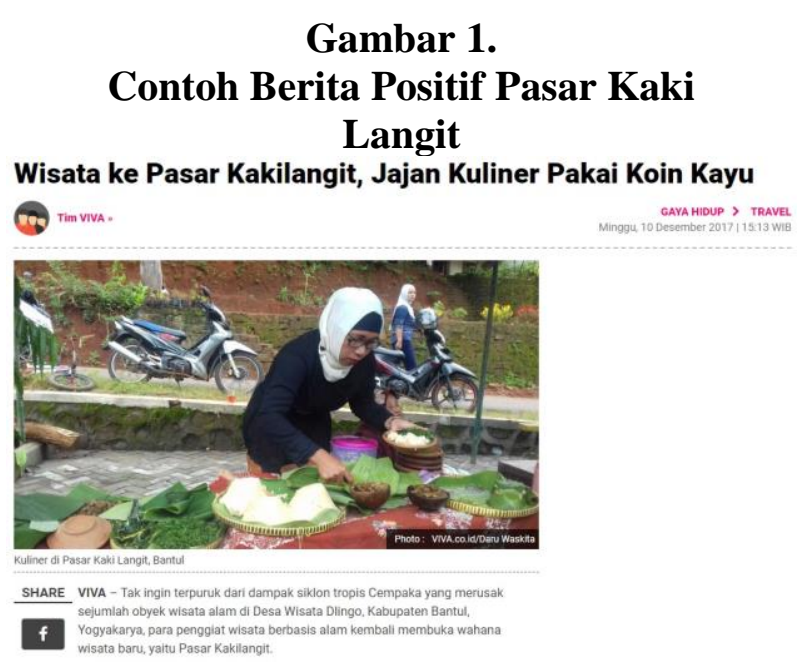

\section{Video Testimoni}

Video menjadi salah satu konten yang sangat berperan penting dalam kesuksesan pemasaran digital. Para buzzer media sosial dalam tim ini lebih banyak memproduksi video dengan menggunakan handphone pribadi. Tujuannya agar video yang dihasilkan lebih beragam dan lebih original. Salah satu tujuan membuat konten video karena untuk lebih mengenalkan Pasar Kakilangit kepada warganet. Video merupakan salah satu bentuk konten kreatif yang paling banyak diminati warganet. Sebab, dalam teknik buzzer, video memiliki kecenderungan yang lebih tinggi untuk dilihat daripada konten lainnya. Dalam penelitian ini, para buzzer media sosial meluncurkan berbagai bentuk video, mulai dari seputar informasi Pasar Kakilangit hingga video testimoni. Berikut beberapa bentuk video Pasar Kakilangit ;

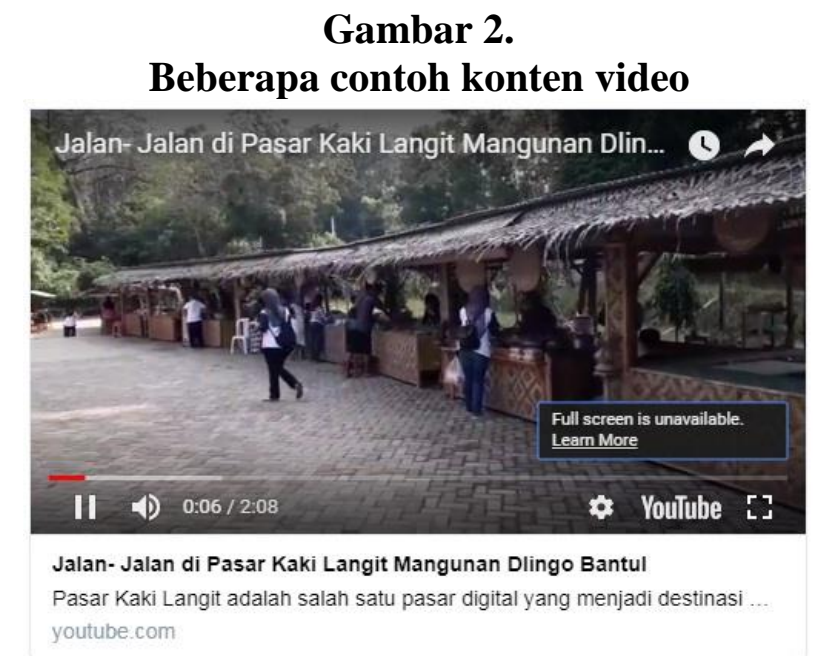

Meme

Meme atau dikenal meme comics merupakan sebentuk tiruan dari berbagai gambar yang telah dikenal akrab (familiar) oleh kalangan pengguna media sosial (warganet). Artinya, meme comics merupakan hasil montase atau rekayasa visual dari sejumlah gambar yang telah populer. Dalam penelitian ini ada beberapa alasan mengapa buzzer media sosial membutuhkan meme diantaranya; Pertama, meme digunakan sebagai bahan atau "amunisi" untuk menyebarkan berita atau apapun yang terkait dengan produk yang dijual di Pasar Kakilangit.

Kedua, meme lebih cepat untuk disebarluaskan dan tentunya lebih cepat beradaptasi dengan kecepatan waktu yang menjadi kontur media sosial. Dalam konteks media sosial, sedikit saja tertinggal, secara otomatis informasi tersebut akan usang dan tidak dapat menarik atensi warganet. Dengan demikian meme merupakan salah satu konten yang sangat diperlukan oleh buzzer dalam pemasaran digital. Selain itu, meme melalui media sosial, lebih mudah diterima oleh para generasi milenial di seluruh Indonesia. Sedangkan jenis meme yang disebar lebih banyak di sebar oleh buzzer media sosial lebih kepada meme yang menginformasikan Pasar Kakilangit Mangunan Yogyakarta. 


\section{Peran Buzzer Media Sosial Dalam Memperkuat Ekosistem Pemasaran Digital}

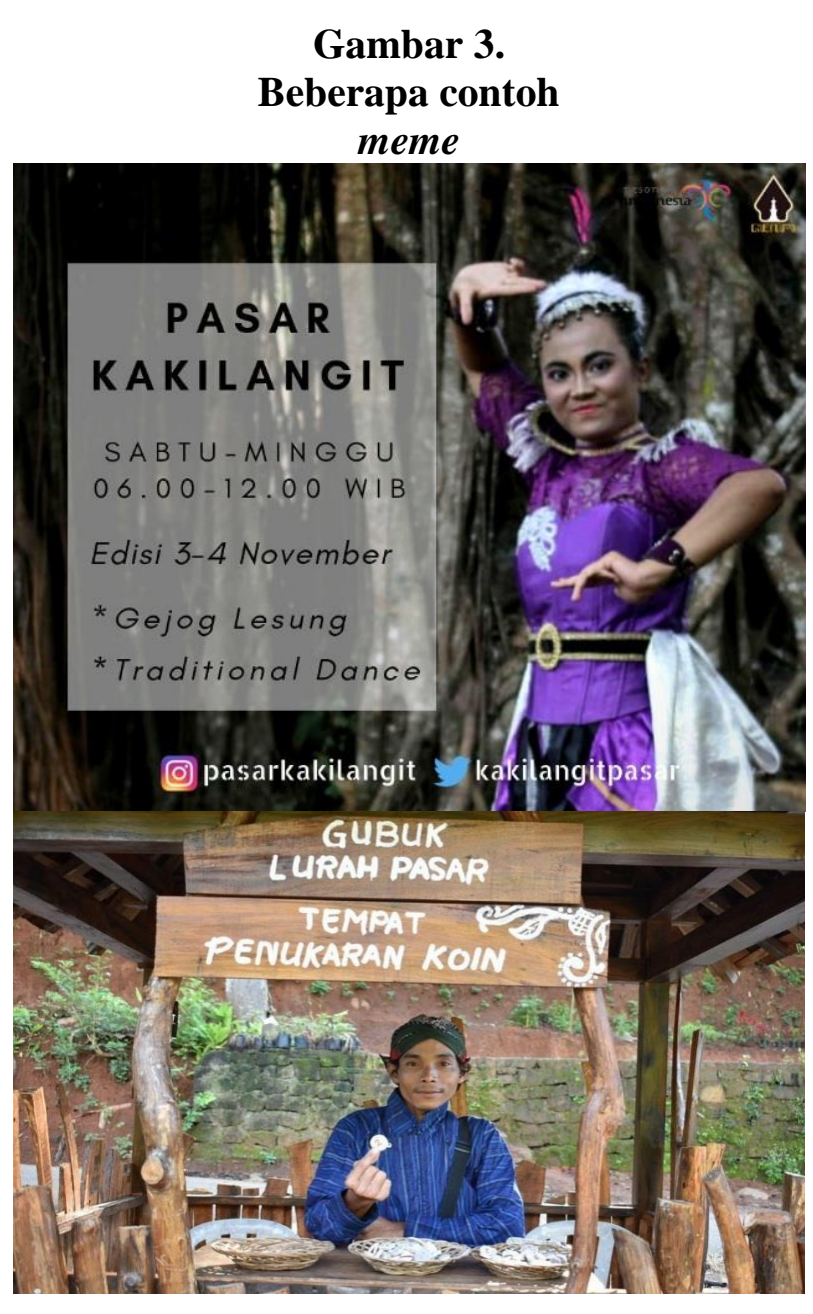

\section{Konten Teks}

Dalam konteks buzzer media sosial, konten berbentuk teks sangat menentukan keberhasilan sebuah produk akan banyak dibaca oleh warganet. Meski demikian konten teks tidak menggunakan foto (image) atau meme. Dikarenakan karakter warganet tentu tidak semua yang menyukai melihat visual seperti video atau foto. Tetapi banyak pula warganet yang lebih menyukai membaca dari cuitan berupa teks di Twitter.

Untuk membentuk buzzer yang ahli dalam konten teks memang diperlukan latihan terus menulis dalam menulis terutama opini populer. Sedangkan, konten teks ini berasal dari narasi tunggal yang telah disiapkan oleh tim buzzer. Dalam persebarannya konten teks menggunakan tagar \#PasarKakilangit yang ditujukan agar bisa memberikan kontribusi agar tagar \#PasarKakilangit bisa cepat masuk di trending topik Twitter. Untuk konten teks, hanya platform media sosial Twitter yang sangat cocok karena memiliki fasilitas pencari kata kunci yang bila diakumulasikan menjadi trending topik.

\section{Gambar 4.}

\section{Beberapa contoh konten} Teks

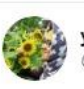 \\ yeni ayu suharso \\ @YeniWimbogo \\ Kesenian yang sudah pernah menghibur pengunjung \\ Pasar Kakilangit diantaranya Gejog Lesung, Gamelan \\ Wong Tuo, dan masih banyak lagi. \#PasarKakilangit \\ \#GenPIJogja \\ 9.50 AM 17 Feb 2018 . Hootsuite
}

\section{Teknik Buzz dan Tagar \#PasarKakilangit}

Teknik buzz merupakan salah satu langkah membangun komunikator yang handal di media sosial. Komunikator inilah yang kemudian dalam konteks bisnis digital disebut sebagai sosok buzzer bisnis. Dengan demikian, keberhasilan pesan yang akan disampaikan sangat tergantung dari bagaimana para komunikator ini bekerja. Dalam teknik buzz marketing seorang buzzer harus bisa menjadi saluran komunikasi digital untuk menciptakan efek mempengaruhi dan menjadi perbincangan luas (viral) hingga kemudian menjadi opini publik. Seringkali buzzer bisnis melakukan promosi pemasaran dengan melempar opini, informasi dan postingan melalui Twitter hingga trending topik dan kemudian ikut disebarkan ke platform Instagram.

Akan tetapi dalam teknik buzz, indikator terpenting agar sebuah produk maupun isu bisa dikenal luas, apabila bisa menembus trending topik Twitter. Meskipun hanya masuk trending topik beberapa jam saja, tetapi ini merupakan indikator keberhasilan dari buzzer bisnis. Oleh sebab itu, biasanya brief yang merupakan narasi tunggal digunakan bersama-sama dan serentak untuk panduan memposting agar bisa menembus 
trending topik Twitter. Sebab bila belum menembus trending topik maka belum dikatakan sukses dalam mempromosikan sebuah produk. Oleh sebab itu biasanya dibutuhkan banyak akun Twitter untuk bisa menembus trending topik. Dengan catatan, harus pula dikondisikan dengan kondisi isu yang sedang berkembang. Apabila ada isu yang banyak dibicarakan warganet di Twitter secara otomatis trending topik akan sulit berada diurutan nomer satu.

Oleh sebab itu buzzer media sosial, bertugas menghasilkan 1000 tweet dalam durasi satu jam. Sebab dengan 1000 tweet dalam durasi 1 jam tentu akan bisa mendorong tagar bisa menembus 5 besar trending topik Twitter. Disinilah peran gotong royong digital antar buzzer media sosial diperlukan. Salah satu bentuknya, adalah para buzzer bisa saling membantu retweet sehingga sebuah konten bisa cepat tersebar luas.

Menurut, Monyo salah satu buzzer media sosial yang berperan dalam membangun branding Pasar Kakilangit melalu tagar \#PasarKakilangit menjelaskan:

"Peran buzzer sangat berperan membangun branding nama Pasar Kakilangit. Itu kami lakukan dengan terus membangun pencitraan melalui tagar yang ada di Twitter hingga mencapai trending topik. Nanti ketika sudah trending topik semua warganet akan mengenal pasar tersebut dan akan ikut membagikan ke semua media sosial mereka masing-masing".

Indikator keberhasilan dari buzzer media sosial ini terlihat dari naiknya tagar \#PasarKakilangit yang memuncaki trending topik Twitter. Berikut beberapa contoh postingan di Twitter yang digunakan untuk menaikan tagar \#PasarKakilangit agar menembus trending topik.

\section{Gambar 5. Contoh postingan di Twitter}

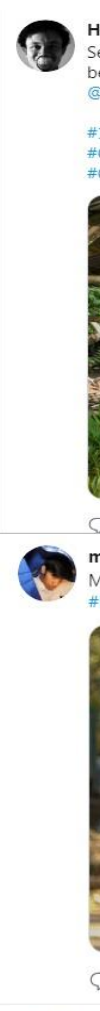

Selamat Wiratama @Hardybreck.Dec 15, 2018 Selamat Ulang Tahun yang Pertama @kakilangitpasar, yuk seru-seruan disini @Rezza_rizki @rizkaita @monyoku @razan_putra @sendoh_aja \#1PasarKakilangit \#DestinasiDigitalJogja \#PasarKakilangit \#GenPIJogja

\#GenPI

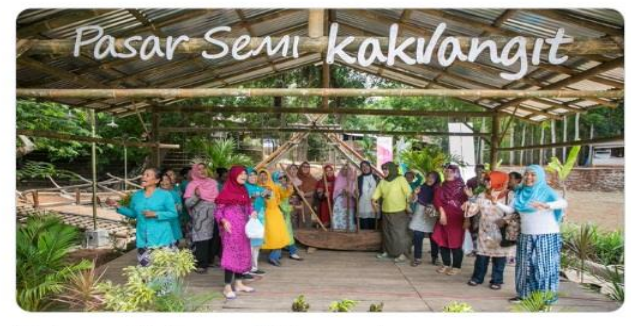

monyoku | IG: @monyoku @monyoku · May 20, 2018

Mas@kaesangp mau ketemu @taniabung di \#PasarKakilangit atau

\#PasarBanyunibo \#golektakjil

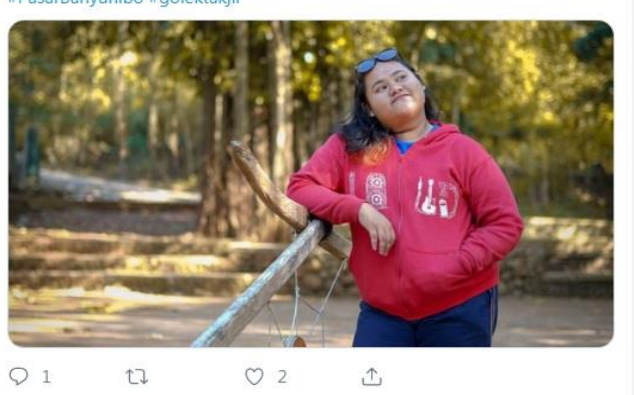

Nyimas Wulandari @nyimaswulandari · Mar 22, 2018

Agar menginspirasi peserta Rakornas yang berasal dari perwakilan 34

provinsi di tanah air. Ada \#PasarKaretan \#PasarPancingan \#PasarKakilangit \#PasarTahura \#PasarBabaBoentjit, \#PasarSitiNurbaya \#PasarMangrove \#PasarSemarangan \#Pasarkaulinan Menes, \#PariwisataZamanNOW.

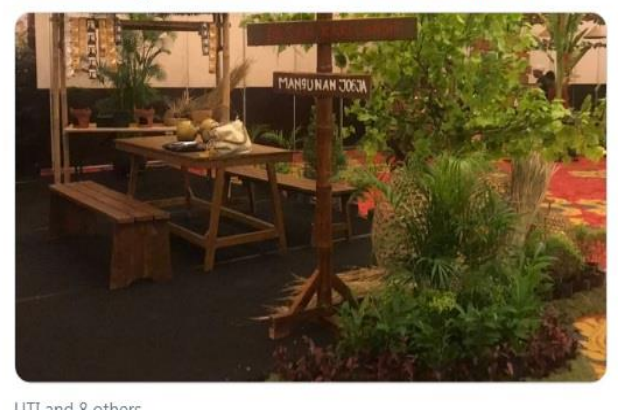

UTI and 8 others

kulineryogya.id @kulineryogya· May 20, 2018

Sebelumnya, @PasarBanyunibo hanya buka di Minggu pagi, mengikuti pola pasar mingguan dari kakaknya, \#PasarKakilangit yang telah dibuka sejak pasar mingguan dari kakaknya, \#PasarKakilangit yang te
Desember lalu di Mangunan. \#NasionalismeZamanNow

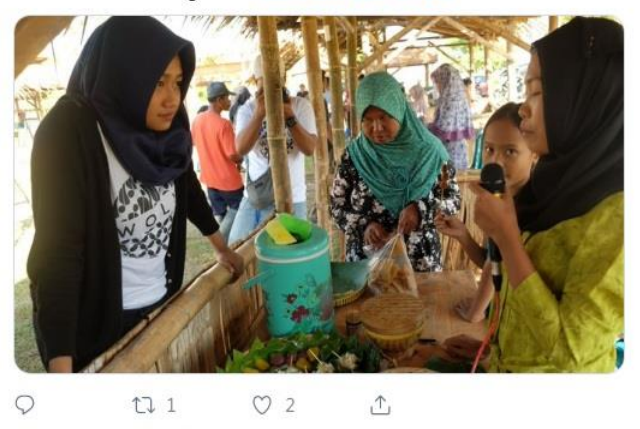




\section{Peran Buzzer Media Sosial Dalam Memperkuat Ekosistem Pemasaran Digital}

\#ceritakhun @ceritakhun.Feb 10, 2018
Ada banyak pilihan menu enak-enak untuk memanjakan lidah

Ada banyak pilihan menu enak
\#pasarkakilangit \#genpijogja

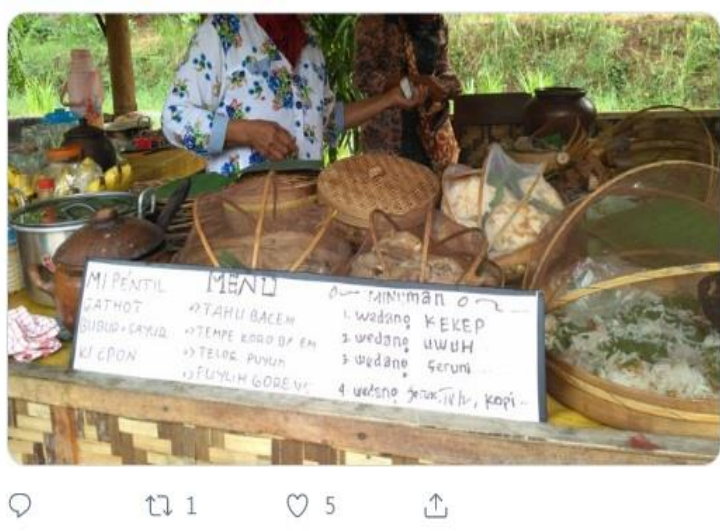

Sedangkan aspek khalayak yang menjadi target utama seorang buzzer media sosial adalah; Pertama, para generasi milenial yang seringkali menggunakan waktunya di media sosial. Kedua, para warganet baik dari dalam maupun dari luar wilayah Yogyakarta. Menurut, Anthekun salah satu buzzer yang berperan dalam membangun branding Pasar Kakilangit melalu tagar \#PasarKakilangit menjelaskan:

"Sedangkan untuk dapat menarik perhatian warganet dan generasi milenial teknik penyebaran yakni dengan bersama-sama mention di akun buzzer secara serentak melalui tagar (hashtag) yang sudah ditentukan. Tujuannya agar tagar tersebut dapat terus menjadi trending topik di media sosial terutama Twitter. Dengan cara kerja bergotong royong atau secara serentak akan membuat tagar \#PasarKakilangit akan memuncaki trending topik Twitter."

Dalam upaya memviralkan sebuah tagar adalah dengan mendorong tagar tersebut menjadi trending topik dan media sosial yang digunakan adalah Twitter. Sebab hanya Twitter yang memiliki fasilitas trending topik. Sedangkan Instagram dalam penelitian ini difokuskan hanya untuk mengkonfirmasi dan memperkuat promosi Pasar Kakilangit secara visual. Artinya, ketika warganet telah melihat tagar \#PasarKakilangit yang sudah menembus trending topik, maka biasanya warganet akan melakukan konfirmasi dengan melihat foto dan video melalui akun Instagram.

\section{Ekosistem Pemasaran Digital}

Dengan teknik ini para buzzer media sosial telah dapat memotivasi para pelaku UMKM untuk memanfaatkan media sosial dalam memperkuat pemasaran produknya. Sekaligus membimbing para pelaku usaha untuk bisa memasarkan produk dan jasanya dengan lebih efektif dan efisien. Dengan begitu, peran buzzer media sosial telah memperkuat para pelaku usaha UMKM belajar untuk bisa tampil inovatif, kreatif dan bersahabat dengan para milenial dalam konteks bisnis digital. Bahkan para buzzer media sosial ini telah dapat membangun budaya baru agar para pelaku UMKM untuk bisa memanfaatkan digitalisasi dan pemasaran digital dalam pengembangan usahanya.

Kehadiran para buzzer media sosial telah dapat memperkuat ekosistem pemasaran digital yang bisa membuat para pelaku usaha UMKM lainnya tertarik dan termotivasi untuk menggunakan media sosial dalam pemasaran digital. Ekosistem yang tumbuh ini kemudian bisa menjadi budaya (kultur) baru bagi para pelaku usaha UMKM dalam upaya memperkuat promosi produknya. Bila para pelaku usaha UMKM bisa dengan baik memanfaatkan teknik ini, tentu kedepan bisa dipastikan akan mendorong tumbuhnya ekosistem pemasaran digital hingga di tingkatan perdesaan. Sebab, mengutip penelitian Bank Dunia bahwa keterlibatan UMKM secara digital termasuk penggunaan media sosial menjadi salah satu pendorong pencapaian target pertumbuhan ekonomi $7 \%$ di tahun 2025 mendatang. 


\begin{abstract}
KESIMPULAN
Peran buzzer media sosial dalam mempromosikan Pasar Kakilangit Mangunan Bantul telah memberikan kontribusi pengetahuan baru tentang pemasaran digital kepada para pelaku usaha. Dengan teknik pemasaran digital para buzzer berupaya mengenalkan para pelaku usaha UMKM dengan berbagai konten dan teknik buzzer dalam memperkuat promosi. Dengan menggunakan konten kreatif seperti; video, meme dan teks, para buzzer media sosial berupaya memperkuat keunikan dari produk yang ditawarkan kepada warganet. Melalui tagar \#PasarKakilangit yang bisa masuk trending topik Twitter Indonesia, para buzzer bersama-sama memperkuat promosi produk Pasar Kakilangit hingga viral dan dikenal luas oleh warganet.
\end{abstract}

Dengan demikian, para buzzer media sosial telah dapat membangun budaya (kultur) baru tentang pentingnya media sosial sebagai saluran pemasaran digital. Langkah yang dilakukan para buzzer yakni dengan ikut memperkuat konten \#PasarKakilangit di media sosial. Selain itu buzzer media sosial telah memberikan pengetahuan baru akan pentingnya trending topik Twitter dalam mempromosikan produk dan jasa kepada para pelaku usaha UMKM. Sehingga kehadiran para buzzer media sosial telah banyak mempengaruhi publik untuk memanfaatkan media sosial seperti Twitter dan Instagram sebagai wahana pemasaran yang efektif serta efisien. Hal ini semakin membuktikan bahwa buzzer media sosial telah berperan memperkuat upaya untuk mempromosikan Pasar Kakilangit secara digital. Dengan begitu, penelitian ini menyimpulkan bahwa peran buzzer media sosial telah memberikan kontribusi positif terhadap upaya memperkuat ekosistem pemasaran digital di Indonesia.

\section{DAFTAR PUSTAKA}

Arianto, B. (2015). Kampanye Kreatif Dalam Kontestasi Presidensial 2014. Jurnal
Ilmu Sosial dan Ilmu Politik UGM. No 1, Volume 19: 16-39.

. (2017). Kampanye Politik Digital

Dalam Kontestasi Presidensial 2014:

Studi Demokreatif dan Jokowi Advanced

Social Media Volunteers (JASMEV)

2014. Tesis. Universitas Gadjah Mada

Yogyakarta

. (2014). Fenomena Relawan Politik

dalam Kontestasi Presidensial 2014.

Jurnal Ilmu Sosial dan Ilmu Politik

UGM. Volume 18, No 2, November (146-162)

. (2019). Buzzer Media Sosial dan

Branding Produk UMKM Daerah

Istimewa Yogyakarta. Jurnal UMKM

Dewantara. Volume 2 Nomor 1 Juli.

Castells, M. (2007). Communication, Power and Counter-power in the Network

Society. International Journal of

Communication, 1(1), 29.

Fahmi, I. (2019). Buzzer Politik dan Demokrasi. Makalah Diskusi MKP Corner UGM. Drone Emprit Academic Universitas Islam Indonesia. Yogyakarta.

Katadata.co.id. (2018). Survei APJII: Penetrasi Pengguna Internet Di Indonesia Capai 64,8.(Online).https://katadata.co.id/berita /2019/05/16/survei-apjii-penetrasipengguna-internet-di-indonesia-capai648, diakses 20 Mei 2018

Kaplan, Andreas M.; Michael Haenlein (2010)

"Users of the world, unite! The challenges and opportunities of Social Media". Business Horizons 53(1): 59-68. Kontan.co.id. (2018). Media Sosial Kebanjiran Iklan.

(Online)

http://internasional.kontan.co.id/news/me dia-sosial-kebanjiran-iklan, diakses 20 Mei 2018

Lancaster \& Massingham. (2010). Global Marketing. In Essentials of Marketing Management. Routledge.

Moleong, Lexy J. 2005. Metodologi Penelitian Kualitatif. Penerbit Remaja Rosdakarya. Bandung.

Moriansyah, L. (2015). Pemasaran Melalui 


\section{BAMBANG ARIANTO}

\section{Peran Buzzer Media Sosial Dalam Memperkuat Ekosistem Pemasaran Digital}

Media Sosial; Antecedent dan Consequences. Jurnal Penelitian Komunikasi dan Opini Publik Vol. 19 No.3 : 457-475.

Kotler \& Armstrong. (2012). Principles of Marketing 14th Edition. New Jearsey: Pearson Education Inc.

Paradistya, A. (2014). Viral Marketing Melalui Twitter: Studi Kasus Pada Situs Web www. sociabuzz. com Dalam Mendorong Terjadinya Viral Marketing Melalui Twitter. Tesis Universitas Gadjah Mada Yogyakarta.

Syahputra, I. (2017). Demokrasi virtual dan perang siber di media sosial: Perspektif netizen Indonesia. Jurnal Aspikom 3, no. 3 (2017) : 457-475.

\section{Wawancara}

Wawancara dengan Monyo, Buzzer dari Genpi Yogyakarta, 15 November 2019

Wawancara dengan Anthekun, Buzzer dari Genpi Yogyakarta, 20 April 2019 